Magdalena Wnuk-Olenicz ${ }^{*}$

\title{
Aktywność edukacyjna uczestników UTW jako kompensacja i/lub kontynuacja rozwoju na przykładzie wybranych biografii edukacyjnych ${ }^{1}$
}

Streszczenie: W artykule autorka przedstawia kompetencyjny model starości jako optymalny dla osób starszych. Stawia pytanie, czy udział w ofercie Uniwersytetu Trzeciego Wieku pozwala na zdobywanie kompetencji, które wymienia literatura gerontologiczna. W dalszej części autorka prezentuje możliwe typy aktywności edukacyjnej charakteryzujące słuchaczy Uniwersytetu Trzeciego Wieku. $Z$ realizowanych badań wynika, że aktywność ta może przybierać formy: kompensacji rozwoju oraz kontynuacji rozwoju. Należy zaznaczyć, że obie funkcje wzajemnie się uzupełniają i nie wykluczają się. Z przeprowadzonych badań wynika, że aktywność edukacyjna w okresie starości pozwala człowiekowi na niezależność, harmonię wewnętrzną, lepszą jakość życia, pozwala żyć twórczo, działać na rzecz otoczenia, służąc mu swoimi kompetencjami i doświadczeniem.

Słowa klucze: starość, model kompetencyjny starości, kontynuacja rozwoju, kompensacja rozwoju, Uniwersytet Trzeciego Wieku, aktywność edukacyjna, aktywność.

\section{Educational activity participants UTW as compensation and/or continuation of development, based on selected educational biography}

Summary: In this article the author presents the competence theory, as optimal for the elderly. Asks the question of whether participation in the offer of the University of the Third Age allows for the achievement of competencies, which lists gerontological literature. In the next part the author

${ }^{*}$ Wyższa Szkoła Humanistyczno-Ekonomiczna w Brzegu, 49-300 Brzeg, ul. Młynarska 12; magdalena_wnuk@poczta.fm

${ }^{1}$ Artykuł przygotowany został na podstawie badań realizowanych do pracy doktorskiej nt. Drogi edukacyjne stuchaczy Uniwersytetu Trzeciego Wieku, w Instytucie Pedagogiki Uniwersytetu Wrocławskiego, pod kierunkiem prof. dr hab. Krystyny Ferenz. 
presents possible types of educational activity characterized by students of the University of the Third Age. From the research shows that this activity may take the form: the development of compensation and continuing development. It should be noted that both functions are complementary and not mutually exclusive. The study shows that educational activity in old age allows people to independence, inner harmony, better quality of life, can live creatively, work for the environment, serving their competence and experience.

Keywords: old age, competence theory, the continuation of the development, compensation development, University of the Third Age, educational activity, activity.

Gdy cel znajduje się w nieskończoności, to i droga do niego wiodąca nie może być wyraźnie wytoczona.

Antoni Kępiński

Starzenie się jest zjawiskiem niezwykle zindywidualizowanym, zależnym od wielu czynników. Dlatego przystosowanie do tego okresu życia jest niezwykle ważne, choć niełatwe/złożone, bo związane z pojawiającymi się deficytami, utratami, obniżaniem się sprawności psychofizycznej. W literaturze psychologicznej, socjologicznej czy pedagogicznej opisane są różnorodne teorie, mające na celu wyjaśnienie przystosowania do starości ${ }^{2}$. Ogólnie rzecz biorąc, odwołują się one do trzech klasycznych teorii: teorii wycofania się, teorii stresu starości i teorii aktywności ${ }^{3}$. Pierwsza mówi o naturalnej i ważnej funkcjonalnie potrzebie rozwojowej człowieka starszego, jaką jest wyłączenie się z życia społecznego. Druga podkreśla konieczność dostosowania się osoby do swoich możliwości oraz wymagań związanych ze zmieniającymi się warunkami społecznymi, ekonomicznymi, cywilizacyjnymi, które działają jak stresory. W teorii aktywności wskazuje się na możliwość podtrzymywania aktywności człowieka starszego w różnych obszarach życia (Steuden, 2011, s. 71-72). Od lat 90. XX w. znaczenia zaczęła nabierać właśnie teoria aktywności, zakładająca udział osób starszych w organizacji życia społecznego, kulturalnego i rodzinnego ${ }^{4}$. Chodzi tu o aktywność różnego typu: intelektualną, społeczną, obywatelską, kulturalną, religijną, fizyczną, domowo-rodzinną, zawodową, towarzyską, klubową, twórczą, osobistą, krajoznawczą, hob-

${ }^{2} \mathrm{~W}$ literaturze mówi się także o adaptacji do starości, które polega na wypracowaniu stylu życia odpowiadającego nowym wyzwaniom, zgodnego z możliwościami i cechami osobowości (Straś-Romanowska).

${ }^{3}$ Obok wymienionych teorii funkcjonują inne, łączące elementy różnych koncepcji: teoria selektywnej optymalizacji Paula Baltesa i współpracowników, koncepcja oscylacji pomiędzy asymilacją i akomodacją Jochena Barandtstadtera i współpracowników, teoria społeczno-emocjonalnej selektywności Laury Carstensen i współpracowników, teoria gerotranscendencji Larsa Tornstama (Steuden, s. 72).

${ }^{4}$ Współcześnie gerontolodzy uważają aktywność za synonim życia. 
bystyczną, opiekuńczą, zawodową, wreszcie wolontariat. Aktywność człowieka starszego jest wskaźnikiem jego jakości życia. Aby godnie żyć, trzeba być aktywnym, w innym przypadku życie przekształca się jedynie w trwanie. Wśród gerontologów uznanie zyskał kompetencyjny model starości, uznający osoby starsze odpowiedzialnymi za nabywanie umiejętności sprostania życiowym trudnościom i radzenia sobie na podstawie własnych doświadczeń i wiedzy, a także za pełnienie ról społecznych przypadających na ten okres życia. Model ten proponuje nabywanie umiejętności zmagania się z zadaniami rozwojowymi poprzez: ciągłe uczenie się lepszego rozumienia siebie i innych, pozyskiwanie wiedzy dotyczącej procesu starzenia się i starości, pozytywne relacje z innymi ludźmi, uczenie się zdolności planowania wydarzeń i ich kontroli (Szwarc, 1988, s. 103-110). Innymi słowy należy zdobywać kompetencje, które umożliwią rozwiązywanie problemów, które przynosi życie. Człowiek rozwojowy to ten, który rozwiązuje swoje problemy, zdobywając w różny sposób na ten temat wiedzę, budując własne kompetencje. Można powiedzieć, że kompetencja to zdolność człowieka do przyjęcia odpowiedzialności za swoje życie i samodzielne jego kształtowanie (ibidem, s. 13). Okazuje się, że dotychczasowe kompetencje stają się niewystarczające. Edukacja do starości powinna odbywać się na przestrzeni życia człowieka ${ }^{5}$. Zagadnienie kompetencji należy rozpatrywać w trzech wymiarach:

a) fizycznym (kompetencja sprowadza się do stanu zdrowia, zdolności fizycznej, braku zapotrzebowania na pomoc i opiekę). Człowiek musi nauczyć się żyć z określoną chorobą, nabytym inwalidztwem, dbać o sprawność fizyczną;

b) poznawczym (kompetencja sprowadza się do inteligencji, pamięci, zdolności uczenia się i rozwiązywania problemów): ćwiczenia umysłu, pamięci (wysiłek intelektualny);

c) społecznym (kompetencja sprowadza się do radzenia sobie ze środowiskiem społecznym): zaangażowanie w życie społeczności lokalnej, znalezienie grupy rówieśniczej, wolontariat itp. (Halicki, 2000, s. 12).

Nasuwa się pytanie, czy udział w UTW, jako kolejny etap drogi edukacyjnej, jaki wybiera sobie osoba w późnej dorosłości, pozwala na zdobywanie owych kompetencji? Czy podejmowana przez słuchaczy aktywność fizyczna, edukacyjna, społeczna, kulturalna itp. jest swego rodzaju programem rozwoju, a więc nabywaniem kompetencji fizycznych, poznawczych, społecznych, kulturalnych? O. Czerniawska proponuje uczenie się starszego człowieka traktować jako styl życia, który zakłada otwartość, gotowość na zmiany, aktywność, reinterpretację przeszłości, własnych doświadczeń, wędrowanie drogą życia z otwartymi oczami, wrażliwe i świadome wobec siebie i innych (Czerniawska, 1996). Niewątpliwie proponowany styl życia należy uznać za optymalny wobec postulatu zdobywania kompetencji życiowych. Dziś wszystko wokół zmienia się bardzo szybko, osoby

${ }^{5}$ Wychowanie do starości jest postulatem formułowanym przez pedagogikę społeczną (A. Kamiński, H. Radlińska). Warto wspomnieć o innym - wychowanie w starości. Dzisiaj wobec prognoz demograficznych wydaje się niezwykle zasadny. 
starsze muszą nadążyć za zmianami, bowiem pojawiają się nowe przyczyny wykluczenia społecznego. Zmienia się model rodziny, wobec czego nawiązywanie międzypokoleniowych relacji wydaje się być niezwykle ważne. W Uniwersytecie Trzeciego Wieku ludzie starsi mogą wybierać, decydując się na aktywność zrzeszeniową. Grupa ta była moją grupą badawczą. Jednocześnie zdaję sobie sprawę, że człowiek starszy może mieć swój własny, indywidualny plan rozwoju, partycypacji w życiu społecznym. Dobrym przykładem będą stulatkowie, których biografie edukacyjne miałam możliwość poznawać podczas projektu „Wrocław dziękuje stulatkom"'.

Analiza biografii edukacyjnych ${ }^{7}$ pozwoliła mi wyróżnić rodzaje/typy aktywności edukacyjnej charakteryzujące narratorów (można to również ująć w kategoriach funkcji, jakie wobec słuchaczy pełni ta placówka):

1. Aktywność edukacyjna jako kompensacja rozwoju, dopełnienie przebytej drogi edukacyjnej (np. realizacją marzeń o studiowaniu z okresu młodości), pokonywanie kryzysów rozwojowych (E. Erikson - integralność ego vs. rozpacz), momentów krytycznych w życiu (np. śmierć współmałżonka), pomoc w akceptacji i rozwiązywaniu problemów, jakie przynosi życie (np. przejście na emeryturę, wdowieństwo, kryzys ,pustego gniazda” po raz drugi, słabnąca sprawność fizyczna, poczucie osamotnienia itp.) - przykład Teresy i Antoniny;

2. Aktywność edukacyjna jako kontynuacja rozwoju, aktualizacja i rekonstrukcja wiedzy życia, kontynuacja pasji poznawczej, dbanie o sprawność intelektualną, fizyczną, pokonywanie stresu starości, zmiany struktur poznawczych (archaicznych, nieadekwatnych do współczesności), zdobywanie nowych kompetencji (komputerowych, językowych, społecznych, kulturowych) - przykład Zofii i Marii.

Kompensacja jest mechanizmem obronnym człowieka opisanym i analizowanym w literaturze psychologicznej. W. Okoń w Stowniku Pedagogicznym definiuje kompensację jako wyrównywanie braków w pewnej sferze działalności jednostki przez nasilenie się aktywności i zaangażowanie tejże jednostki w innej sferze. Dobitniej w tej kwestii wypowiada się Józef Rembowski, gdy opowiada się zdecydowanie za teorią aktywności w gerontologii, stwierdza: „Aktywność jest potrzebą psychiczną i społeczną w każdym wieku, nie wyłączając późnych lat życia człowieka. Tak więc ludzie starzy są zadowoleni z siebie, jeśli w ich zachowaniu ujawnia się działanie zastępcze po utracie roli pierwotnej”. To wyjaśnia istotę funkcji kompensacyjnej rozwoju.

Czym jest rozwój człowieka w późnej dorosłości? Na pewno nie jest synonimem uczenia się. W przypadku człowieka dojrzałego jest często reedukacją,

${ }^{6}$ Zainteresowanych odsyłam do tekstu Wnuk-Olenicz, 2010.

${ }^{7} \mathrm{~W}$ latach 2009-2011 w ramach przygotowywanej pracy doktorskiej zrealizowałam dwadzieścia wywiadów swobodnych z elementami narracji ze słuchaczami Uniwersytetów Trzeciego Wieku z Wrocławia, Jeleniej Góry oraz Brzegu. Wybrane fragmenty biografii edukacyjnych są próbą analizy zrealizowanych wywiadów. 
pozbywaniem się pewnych przyzwyczajeń, postaw, schematów działania, które nie sprzyjają dobremu samopoczuciu i są nieadekwatne do zmieniającej się rzeczywistości. Warto ów rozwój odnosić do trzech wymiarów:

1) sprawności umysłowej, inaczej intelektualnej;

2) rozwoju duchowego, osobistego związanego z psychologicznym wymiarem człowieka;

3) zdobywania nowych kompetencji niezbędnych w pokonywaniu kryzysów rozwojowych charakterystycznych dla omawianego okresu życia.

Rozwój i edukację w okresie późnej dorosłości należy także odnieść do porządkowania wiedzy życia, wiedzy biograficznej, którą ludzie starsi noszą w sobie, do budowania pozytywnego bilansu życia. Nie powinny one skupiać się wyłącznie na aktualizowaniu braków, które mogą prowadzić do obniżenia samooceny. Obok działań edukacyjnych o charakterze kompensacyjnym muszą pojawiać się takie, które będą umiejętnie wykorzystywały kompetencje, mądrość życiową oraz biografię osób starszych, np. warsztaty biograficzne, andragogiczne.

Dobrym przykładem ilustrującym aktywność edukacyjną jako kompensację rozwoju będzie biografia edukacyjna Teresy urodzonej w 1939 r., obecnej liderki Wrocławskiego UTW. Po nieudanym starcie do liceum ogólnokształcącego podjęła naukę w technikum geodezyjnym, która trwała dwa lata. Szkoła nie spełniała jej oczekiwań, dlatego zmieniła ją na technikum ekonomiczne. Po zakończeniu edukacji w technikum ekonomicznym rozpoczęła pracę w Magazynach Kolejowych PKP (16 lat pracy), a potem w Dyrekcji Kolejowej (21 lat), gdzie pracowała do emerytury. Obecnie mieszka z mężem i dorosłym synem we Wrocławiu. W UTW uczestniczy od 11 lat.

O Uniwersytecie Trzeciego Wieku dowiedziała się od siostry, która obejrzała reportaż w telewizji. Dodatkowo koleżanki mówiły, że jest taka placówka we Wrocławiu. Siostra przekonała narratorkę: Zobacz, już jesteśmy po pracy, dzieci odchowane, możemy coś dla siebie zrobić. Bardzo żałuje, że nie udało jej się podjąć studiów w okresie młodości: Widzi Pani, Marysia starsza ode mnie i ma skończone studia, a ja młodsza i niestety. Siostra pomogła dzieciom w wychowaniu wnuków, kiedy podrosły i poszły do szkoły, uznała, że czas zrobić coś dla siebie: I chciała, żebym ja téz miała jakąś odskocznię. Narratorka pojechała z dziećmi nad morze na wakacje, a siostra stała w kolejce dwa dni, żeby się dostać do UTW. Działo się to w roku 2001: I zostałyśmy przyjęte dzięki temu, że na parterze otworzyli druga aule placówki, w której powtarzane byly wykłady, realizowane w dużej auli. Myśmy byty na liście rezerwowej. Sto osób przyjęli na warunkowa listę i myśmy się załapały. Od samego początku narratorka brała czynny udział niemal w pełnej ofercie programowej: Zaczęłam działać w sekcji wzajemnej pomocy, potem w sekcji kulturalnej, chciatam mieć jak najwięcej zajęć, wszystko mnie interesowało. Do każej pracy, gdzie była potrzeba to ja się zgłaszałam. Odżyła pasja fotograficzna, którą rozbudził wcześniej w technikum nauczyciel fizyki. W domu nie było aparatu, ale mąż miał sprzęt fotograficzny: [...] wywo- 
tywało się $w$ domu, to nie tak jak teraz, że zrobisz i niesiesz do fotografa. Mą̇ cały sprzęt miat. W wannie wywoływaliśmy, także to była i jego i moja pasja. Do dzisiaj mamy ten stary sprzęt. Syn też pasjonuje się fotografia. Tez zawsze dobry aparat chcial mieć, to kupowało się. Odeszła pani, która dotychczas zajmowała się fotografowaniem, reportażami, prowadziła sekcję fotograficzną: [...] ja pomyślałam, to ja spróbuję. Miałam swój aparat, bo nie chciałam z tego korzystać, tu sa przecież $i$ aparat $i$ kamera, ale ja wolę mieć swój sprzęt. I ja pomyślałam, to ja się tym trochę zajme $i$ zobacze jak to mi wyjdzie. Fotografowatam wszystkie uroczystości, wydarzenia, spotkania, zdjęcia byly wykorzystywane do kronik. Uniwersytet jest dla narratorki bardzo ważny, ma tutaj swoje zajęcia, obowiązki, pomaga przy redagowaniu „Kuriera UTW”, czuje się potrzebna. Stara się godzić swoją aktywność w UTW z obowiązkami domowymi, choć podkreśla, że udało jej się od nich w dużym stopniu uwolnić: Ile można $w$ domu pracować, niech inni $w$ domu też maja zajęcie, prawda. Szczególnie maż. A to, co do mnie należy to ja zrobię, pranie, prasowanie, gotowanie. Mąz robi opłaty, zakupy, teraz ma zajęcie, on nie wiedział gdzie się robi opłaty, on nigdy wcześniej tego nie robit. On dużo czyta, czego ja nie mogę o sobie powiedzieć, bo jak ja przychodze zmęczona, to jak się położę, to przeczytam dwie, trzy kartki i śpię. Chociaż przed ta konferencja ostatnia (z okazji 35-lecia), ale ja się tak zawziętam, chyba pięć książek przeczytałam. Dostałam od siostry, bo Marysia dużo czyta i zainteresowata mnie. Ale nie kładłam się do łóżka, tylko siedziałam w fotelu i czytałam. Zapytana o korzyści, jakie daje jej przynależność do tej placówki, mówi: Mam takie wrażenie, że od kiedy tutaj chodzę, to moje życie nabralo jakiegoś innego wymiaru, że ja mam coś dla siebie. Bardzo cieszą ją podróże, o których zawsze marzyła, na które nie było wcześniej czasu i możliwości: [...] zaczęły się wyjazdy. Zaczęło się od tego, że zwiedziłam Kraków, Warszawę, w Muzeum Powstania byliśmy, i w Zakopanem byliśmy, wszystko dzięki Uniwersytetowi. Byliśmy w Dreźnie, a później z projektu to bytam w Grodnie, dwa razy we Lwowie $i$ w Paryżu i teraz Madryt czeka znowu. I w przyszłym roku jedziemy do Turcji, tam się kończy projekt. Mąz byt bardzo przeciwny, jak się dowiedziat, że lecimy samolotem. Ja mówię: „, Stuchaj w życiu nie leciałam samolotem, to widocznie tak musi być, nie martw się, każdy ma zapisane, co ma być”.

Jeszcze inne wymiary tej funkcji prezentuje sobą droga edukacyjna Antoniny urodzonej w 1936 r. (realizacja marzeń o studiowaniu z okresu młodości, funkcja zastępcza po utracie roli pierwotnej - kontynuacja aktywności zawodowej, służy swoim mistrzostwem w zawodzie). Na naukę w okresie dzieciństwa i młodości nie mogła poświęcać zbyt wiele czasu, z uwagi na liczne obowiązki w domu. Bardzo dużo pomagała mamie, ojciec był mocno schorowany. Ukończyła technikum ekonomiczne, potem pracowała w księgowości. Obecnie mieszka sama we Wrocławiu, jest po rozwodzie. W UTW uczestniczy od siedmiu lat.

Do Uniwersytetu Trzeciego Wieku trafiła przez koleżankę z pracy, która wcześniej odeszła na emeryturę i już należała do społeczności UTW. Wiele opo- 
wiadała narratorce o swojej aktywności w placówce, o zaletach, jakich doznaje z przynależności do placówki. Bardzo ją zachęcała. Narratorka zaraz po przejściu na emeryturę zajęła się chorą mamą, zamieszkała z nią, opiekowała się: Kiedy mama zmarła, to ja sobie przypomniałam o UTW. Zadzwoniłam do Ani i poprosiłam ja, żeby mi powiedziała, jak moge się tutaj dostać. Przyszłam, nie liczac bardzo, że będę przyjęta. Przecież jest rozmowa kwalifikacyjna. Zreszta nie bytam w 100\% przekonana, ż ja chce tu być. Dtugie lata byłam sama, ale nie byłam nigdy samotna. Ja cate życie czytam, albo się czymś interesuję, ja nie potrafitam usiaść w oknie i narzekać, że to i tamto. Ja nie odczuwałam samotności. Zawsze się udzielałam społecznie. W stanie wojennym dużo pomagałam. Zawsze znajdowałam sobie zajęcie, nie czułam się zmęczona, narzekajaca, to nie mój charakter. Ale przyjęli mnie i znalazłam się w UTW. Jestem tu siódmy rok. Jak tu przyszłam tylko Anię znałam, ale później poznałam inne osoby. Pani Antonina w UTW niejako kontynuuje swoją aktywność zawodową, która daje jej wiele radości i satysfakcji: Ustyszałam jak przewodniczaca Zarząu mówiła przed wykładem poniedziatkowym, że potrzebuja kogoś do księgowości, zapraszała z sali do wspótpracy, a ja siedzę i myślę, przeciez mogłabym pomóc, ale czy ja dam radę? Przeżywałam strasznie czy się zgłosić, w końcu rozsądek zwyciężyt, myśle sobie, pani prosi, żeby pomóc, trzeba pomóc. Pani odestała mnie do osoby, która troche prowadziła te papiery, i tak zostałam i znów się udzielam.

O swoim udziale w społeczności UTW mówi: Uniwersytet daje mi obowiazek, czegoś się podjęlam, ten obowiazek, że ja muszę wstać, ja mam zaplanowany czas, ja muszę wyjść, mnie czekają poniedziatkowe zajęcia. Ja cate życie żłam w kompleksach, a z tego Pani Madziu człowiek się już nie wyleczy. Teraz jak patrze na młodych to inny mam oglą, widzę, na co trzeba zwracać uwage. Ale nie mam pretensji do moich rodziców, żyli w innym świecie, w innych warunkach. W Uniwersytecie narratorka nawiązała się wiele przyjaźni, panie wzajemnie się odwiedzają, troszczą się o siebie. Kontynuuje aktywność zawodową, pełni bardzo ważną funkcję w placówce. Bardzo sobie ceni, że jest studentką Uniwersytetu.

Aktywność edukacyjną jako kontynuację rozwoju prezentuje sobą Zofia urodzona w 1923 r., która sformułowała dwa motta życiowe: Ja zawsze uważałam, ̇̀ ja się ciagle chce uczyć, że ja jestem entuzjastka nauki; Człowiek powinien pilnować się, żeby być strawnym dla innych. Jeszcze przed wojną ukończyła gimnazjum i zrobiła tzw. „małą maturę” na tajnych kompletach. Po zakończeniu nauki w liceum ogólnokształcącym, znając trzy języki obce, marzyła o studiowaniu handlu zagranicznego (brała także pod uwagę historię, medycynę i stomatologię). W 1945 r. rozpoczęła studia w Szkole Głównej Handlowej w Warszawie. Kiedy odchowała córki rozpoczęła pracę zawodową. Najpierw kilka lat pracowała w Fabryce Maszyn Papierniczych jako zastępca głównego księgowego, a potem jako główna księgowa najpierw Dolnośląskich Zakładów Wyrobów Papierowych, a potem w Karkonoskich Zakładach Papierniczych. Tu pracowała do emerytury, ostatnie trzy lata pełniła obowiązki za- 
stępcy dyrektora ds. ekonomicznych. Obecnie mieszka sama w Cieplicach, jest wdową. W UTW jest słuchaczką od dziewięciu lat, za namową przyjaciółki: Szukałam sobie zajęcia, dalszego rozwoju, sportu. Tu to wszystko znalazłam: na basen chodze raz $w$ tygodniu, na Tai-Chi, na gimnastyke, na wyktady, na język angielski. Bardzo przyjemnie. Uniwersytet nie zmusza do wszystkiego to jest bardzo wazne, czlowiek bierze udziat $w$ tym, w czym chce, nic nie musi, to jest bardzo ważne. Bardzo przeżyła śmierć męża, byli ze sobą mocno związani, czasowo straciła radość życia: Córki mi mówiły, że nie można było się ze mna dogadać, że nie wychodziłam z domu, że nie dbałam o siebie, ale to UTW mnie wyciagną z tego. Rozpoczęła też przygodę z kabaretem, który bardzo prężnie działa w Karkonoskim UTW, pod nazwą „Bella mafia”: Kiedy Danusia (szefowa kabaretu) zaczęta organizować kabaret, to ja powiedziałam, że mam takie rzeczy, skecze różne, piosenki przedwojenne, nadajace się do kabaretu i ona mnie w ten sposób zwerbowata. Wystapitam gościnnie a potem to się zaczęto. Nigdy wcześniej takich rzeczy nie robiłam, chociaz jak chodziłam do gimnazjum to mieliśmy drzwi w drzwi takich sąsiadów, mieli córkę i syna i jak do nas przychodzili to odstawialiśmy filmy, przedstawienia, taka była zabawa. O przynależności do wspólnoty UTW mówi: Dużo przyjemności czerpiemy z obcowania z innymi. Wszyscy się lubimy $i$ wszyscy jesteśmy dla siebie mili.

Narratorka jest osobą aktywną, także poza UTW: Co dwa lata jeżdżę na zjazdy, przyjeżdżaja tam ludzie z całego świata. Ludzie, którzy nie wrócili do Polski komunistycznej, zostali w Anglii, w Stanach. Mam kontakt z tymi osobami. Jestem członkiem Stowarzyszenia Rodzin Wojskowych Osadników, ojciec miat pod Grodnem osade, pięknie położona nad dopływem Niemna, $3 \mathrm{~km}$ do Niemna, tam spędzaliśmy cate wakacje.

Nie boi się nowości, zresztą nigdy nie miała do nich lęku: przejęła prowadzenie domowego budżetu po mężu, opanowała obsługę komputera, opłaca rachunki przez Internet, ma kontakt mailowy z wnuczką, która przebywa w Stanach. Dla rozrywki układa pasjansa w komputerze. Chodzi z kijami do Nordic Walking, pomagają $\mathrm{w}$ zachwianiach równowagi, czuje się z nimi pewniej. W wolnym czasie lubi oglądać komedie romantyczne, np. Pretty woman: Mam dużo kaset, lubie stuchać muzyki. Mam jedna kasetę z wywiadem mojego męża, jak chce go ustyszeć to sobie puszczam. Uważa, że w życiu ważna jest uczciwość, marzenia i cele, a czlowiek powinien pilnować się, żeby być strawnym dla innych. Marzy o podróży do Paryża.

Droga edukacyjna Marii urodzonej w 1928 r., jest również przykładem aktywności edukacyjnej jako kontynuacji rozwoju. W czerwcu 1945 r. zdała maturę (nie mając ukończonych 18 lat), dwukrotnie próbowała dostać się na stomatologię we Wrocławiu. Rozpoczęła naukę w Wyższej Szkole Pedagogicznej w Katowicach, z której po roku zrezygnowała. Ukończyła geografię we Wrocławiu. Potem pracowała w Biurze Prognoz i Stacji Meteorologicznej we Wrocławiu. Po przejściu na emeryturę pomogła córce w opiece nad bliźniaczkami. Kiedy 
dziewczynki rozpoczęły naukę w szkole, Pani Maria odnalazła UTW. W UTW jest od 11 lat, mieszka z córką i wnukami we Wrocławiu. Wspomina, że nie łatwo było się dostać do placówki: Wzięłam koleżankę z pracy, przyszłyśmy tu do UTW, kolejka ogromna, chodza z ankietami, mówia, że ankiet już nie ma. Zamieszanie. I kandydaci stali i ci starzy stuchacze. Wreszcie przyszła pani Kierownik i mówi do wszystkich: „Proszę Państwa, do 15 października, ja mam obiecane, że będzie możliwość przyjęcia większej liczby osób, tylko nie wiem czy na pewno, proszę się 15 października dowiedzieć czy to jest aktualne”. W tym czasie wyznaczyła osoby do stolika, żeby zapisywaty na listę wszystkich, którzy chca się zgłosić. Zapisatam też siostrę. Ona była nad morzem. W późniejszym czasie dowiedziała się, że została przyjęta razem z siostrą: Jak ja się ucieszyłam! Obdzwoniłam koleżanki i mówię: „Zaczynamy rok!’”. Pani Maria jest aktywną słuchaczką, uczestniczy w wykładach, chodzi na gimnastykę pleców, na język niemiecki, na moduły psychologiczne, należy do sekcji wzajemnej pomocy, uczestniczy w seminarium księdza F. Głoda. W lektoracie uczestniczy już dziesięć lat: [...] ja traktuję naukę tego języka jako gimnastykę mózgu, bo się trzeba przygotować, bo nie wypada nie wiedzieć. Może już tyle nie zostaje $w$ pamięci, ale kontakt jest. Nawet teraz, jak sa wakacje, ja mam taka kolezanke, z którą chodzimy na niemiecki, my się spotykamy raz w tygodniu i sobie powtarzamy, nawet jutro mamy spotkanie. Od początku uczestniczyła w seminarium gerontologicznym, z którego trzeba było zrezygnować: [...] bardzo ciekawe, wspaniałe spotkania, ale teraz już trzeba miejsce zwolnić młodszym rocznikom. W przeszłości więcej uczestniczyła w proponowanych zajęciach, teraz, jak sama podkreśla, zwolniła tempo z powodów zdrowotnych, jednak z aktywności nie rezygnuje całkowicie: Ja muszę być w ruchu, bo ja miałam zawat sześć lat temu, dyplom teraz dostałam na 35 lecie za aktywność fizyczna. Trzeba się ruszać, sama też $w$ domu się gimnastykuję. Na wykładach poniedziatkowych to zawsze jestem, ja mam gimnastyke o 9.00, ide szybciutko po gimnastyce na górę i sprzedaje „Kuriery UTW” z koleżanka i na wykład na 12.00. Kolportaż Kurierów to do nas należy, rozliczenia, wysyłamy je na cała Polskę. UTW jest dla Pani Marii drugim domem, tu ma grono towarzyskie, z którym spotyka się także poza placówką: Na imieniny, na różne uroczystości się spotykamy. Najważniejsze sa moje imieniny 15 sierpnia, spotykamy się zawsze. Interesuje się turystyką: $W$ tym roku byłam na dwóch dużych wycieczkach, w Puławach, Sandomierzu, Kazimierzu i w Warszawie byłam. To z sekcji turystycznej, u nas działającej bardzo prężnie. Co roku jeździ do Łeby, gdzie jest placówka meteorologiczna. Koleżanka z pracy zbudowała z mężem dom i zaprasza co roku wszystkie koleżanki z rodzinami: Ona jest bardzo przyjazna, bardzo przyciaga do siebie ludzi. U niej jest wspaniała atmosfera. Te instytutowe koleżanki, my bytyśmy bardzo zintegrowane także przez dziatki, które miałyśmy obok siebie, przez lata je uprawiałyśmy. Teraz moja działka jest zaniedbana, nie mam sity pracować, tylko zbieram. Dzieci zawsze na mnie krzyczały, po co ja tam jeżdże, ja mówię: „towarzysko (;)”. A to trzeba jeszcze dwa kilometry od autobusu 
iść w jedna stronę. Już raz byłam w tym roku. W druga stronę po koleżankę mąż przyjechat i samochodem wracałyśmy. Córka i zięć bardzo się cieszą, że narratorka jest zaangażowana w UTW, widzą, że aktywność ta dostarcza jej wiele radości i satysfakcji: Wnuki zawsze jak mi życzenia skladaja to pytaja: , ,Jak tam babciu, jakie wyniki w nauce?”.

\section{Próba podsumowania}

Analiza materiału biograficznego jednoznacznie pokazuje, że aktywność edukacyjna w późnej dorosłości odgrywa znaczącą rolę w zachowaniu dobrego stanu zdrowia psychicznego, fizycznego i społecznego. Aktywność ta przybiera postać zarówno kompensacji, jak i kontynuacji rozwoju człowieka. Myślę, że trudno jest umieścić na dwóch przeciwstawnych biegunach kompensację i kontynuację rozwoju. One współwystępują, uzupełniają się. Podejście komplementarne będzie sprzyjało pełnemu rozwojowi człowieka starszego. Indywidualne biografie mogą różnicować sytuację. Oprócz wymienionych w literaturze zadań rozwojowych charakterystycznych dla tego okresu życia, pojawiają się nowe, mające indywidualny wymiar, zależne od jednostkowych losów, potrzeb i możliwości, a więc biografii.

Okres starości jest etapem życia, w którym człowiek doświadcza wielu trudnych momentów (utrata osób bliskich, zła diagnoza lekarska, nabyta niepełnosprawność itp.). Człowiek rozwojowy musi rozwiązywać problemy, które przynosi mu życie, a więc akceptować i rozumieć sytuacje, z którymi styka go los. E. Erikson pisze, że w tym okresie życia człowiek musi zmierzyć się z kryzysem: integralność ego vs. rozpacz. Rozpacz może być powodowana stresem starości, depresją, utratą sensu życia, negatywnym bilansem życia. To czas, kiedy człowiek starszy ciągle coś traci: status społeczny, status materialny, samodzielność, atrakcyjność, zdrowie, najbliższe osoby. Zmniejsza się jego przestrzeń życiowa. Powoduje to złe scenariusze starości, negatywny bilans życia. W opozycji pojawia się wola odbudowy sensu życia, chęć pokonania depresji, akceptacja choroby, mniejszej atrakcyjności. Jednak nie każdy człowiek jest gotowy, aby samodzielnie poradzić sobie z tymi sytuacjami. Niektórym potrzebna jest pomoc, wsparcie, grupa społeczna, grupa rówieśnicza, udział w edukacji. Jako badacz i edukator osób starszych obserwuję, że człowiek w jesieni życia może pozostawać aktywny intelektualnie, zdobywać nowe kompetencje, rekonstruować istniejące, realizować siebie, dojrzewać w człowieczeństwie. Aktywność edukacyjna w tym wieku pozwala człowiekowi na niezależność, harmonię wewnętrzną, lepszą jakość życia, pozwala żyć twórczo, działać na rzecz otoczenia, służąc mu swoimi kompetencjami i doświadczeniem. Regres w tym okresie życia jest nieuchronny, natomiast rozwój jest możliwy, czego dowodem są zaprezentowane sylwetki słu- 
chaczek UTW. Można by znaleźć w sylwetkach tu przywołanych potwierdzenie tezy zgłoszonej przez wybitnego filozofa i pedagoga Johna Deweya „Edukacja nie jest przygotowaniem do życia, ona jest życiem".

\section{Literatura}

Czerniawska O., 1996, Uczenie się jako styl życia, [w:] M. Dzięgielewska (red.), Przygotowanie do starości, Łódź.

Halicki J., 2000, Edukacja seniorów w aspekcie teorii kompetencyjnej. Studium historyczno-porównawcze, Białystok.

Steuden S., 2011, Psychologia starzenia się i starości, Wydawnictwo Naukowe PWN, Warszawa.

Szwarc H., 1988, Uniwersytet Trzeciego Wieku a jakość życia ludzi starszych, Kalendarz Caritas, Warszawa za: S. Steuden, 2011, Psychologia starzenia się i starości, Wydawnictwo Naukowe PWN, Warszawa.

Wnuk-Olenicz M., 2010, Spotkania nakarmione historiami życia. Czego nauczyli mnie wroctawscy stulatkowie?, [w:] W. Horyń, J. Maciejewski (red.), Nauczyciel andragog we współczesnym społeczeństwie, Wrocław. 